\title{
Multi-demand Analysis of College English Curriculum Setting from the Perspective of General Education
}

\author{
Hong Zhang \\ School of Foreign Languages, Hubei University of Chinese Medicine, Wuhan, 430065, China \\ E-mail: 2532315351@qq.com
}

Keywords: College students, English curriculum setting, General education, Multi-demand analysis.

\begin{abstract}
Only with knowledge of English, College students no longer gain an edge in the 21st century with increasingly fierce competition and frequent international exchanges. College English, a required and basic course for undergraduates in non-English majors, is an important part of general education. English as the lingua franca is not only a tool for communication, but also a carrier of culture. English curriculum reform, therefore, should never be treated as isolated. We should draw on the ideas and methods of general education, set a new English curriculum system, propose effective measures for the reform of college English curriculum and improve the quality of English teaching. College English curriculum reform based on general education will better achieve the goal of college English teaching, broaden the students' horizons, open their minds, foster their ability of independent thinking, enhance their cultural literacy to make them the real "whole man" in the idea of general education.
\end{abstract}

\section{Introduction}

General Education in a Free Society-Report of the Harvard Committee published by the Harvard University Press in 1945 has been widely accepted by the higher education community in terms of its exposition of the status and role of general education in higher education, and the relationship between general education and special education. Few scholars studied college English curriculum setting from the perspective of general education. The scattered studies on the theories and practices in this aspect are far from systematic. To date, the research on college English curriculum has been concentrated on the following aspects. Li Manli, Wang Yongquan (1999) and Chen Xiangming (2006) studied the connotation of general education. [1] In the opinion of Huang Junjie (2006), deepening general education is the very way of improving college students' local cultural literacy and rebuilding the self-study ability in college education. [2] In addition to comprehensively analyzing the history and reality of general education from the horizontal and vertical perspectives, Li Jia (2010) also stressed the general education about foreign languages in each chapter of the book. [3]Wu Dingmin, Han Yajun (2010), Chen Jianlin, Gu Shimin (2011), Wang Yi and Wang Weiqian (2012) studied college English teaching from the perspective of general education. [4]The General Education Research Group at the Institute for Advanced Studies in Humanities and Social Science of Beihang University (2013) not only distinguished between the concepts of general education and separately compared the modes of general education at home and abroad, but also evaluated the general education at home and gave an outlook for it.

\section{Status quo of college English curriculum setting}

College English is a required course for non-English majors. It is the English course for undergraduates in non-English majors, who are the objects of this study. This section mainly views the overall situation and gives a preliminary evaluation of the current college English curriculum setting from the two aspects of implementation and supporting systems. 
The research object of this study includes undergraduates in such majors as Literature, Law, Science and Engineering, Economics and Management from Hubei University, Wuhan University of Science and Technology, and Hubei University of Technology. Questionnaire survey was carried out randomly among them. The convenience of questionnaire collection and range of majors were mainly considered during the selection of samples. A total of 300 questionnaires were distributed from April 2016 to December 2016, of which 280 were returned. The recovery rate is 93.3\%. Among the 280 ones returned, 10 invalid ones were excluded, so the effective rate is $90 \%$. In this survey, 270 valid questionnaires were collected.

\subsection{Opinions on the importance of college English learning}

The undergraduates' opinions on the importance of college English learning were divided into extremely important, fairly important, important, less important and not important according to Likert Scale. The results are shown in Table 1.

Table 1 Opinions on the importance of college English learning

\begin{tabular}{|l|l|l|l|}
\hline Question & Degree of importance & Number of persons & Percentage \\
\hline \multirow{2}{*}{$\begin{array}{l}\text { To what degree do you } \\
\text { think English learning is }\end{array}$} & Extremely important & 228 & $84.4 \%$ \\
\cline { 2 - 4 } important during the & Fairly important & 24 & $8.9 \%$ \\
\cline { 2 - 4 } \multirow{2}{*}{ undergraduate study? } & Important & 14 & $5.2 \%$ \\
\cline { 2 - 4 } & Less important & 3 & $1.1 \%$ \\
\cline { 2 - 4 } & Not important & 1 & $0.4 \%$ \\
\hline
\end{tabular}

As illustrated in Table 1, the percentages of undergraduates who regard college English learning as extremely important, fairly important and important are respectively $84.4 \%$, $8.9 \%$ and $5.2 \%$, while $1.1 \%$ and $0.4 \%$ of the undergraduates believe that college English learning is less important and not important. As can be seen from the percentages, the importance of English has been widely recognized by the undergraduates for it has been the most widely used international language tool since China's entry into WTO and the increasingly frequent international exchanges. The majority of undergraduates assume that English learning is extremely important and essential during the undergraduate study, reflecting that the undergraduates attach importance to English and recognize its positive role in improving their comprehensive quality and competence.

\subsection{Undergraduates’ enjoyment of college English course}

Table 2 Enjoyment of college English course

\begin{tabular}{|l|l|l|l|}
\hline Question & $\begin{array}{l}\text { Degree of } \\
\text { enjoyment }\end{array}$ & $\begin{array}{l}\text { Number of } \\
\text { persons }\end{array}$ & Percentage \\
\hline \multirow{2}{*}{$\begin{array}{l}\text { Do you enjoy the } \\
\text { English class? }\end{array}$} & Extremely enjoy & 22 & $8.1 \%$ \\
\cline { 2 - 4 } & Fairly enjoy & 57 & $21.1 \%$ \\
\cline { 2 - 4 } & Enjoy & 89 & $33 \%$ \\
\cline { 2 - 4 } & Not that enjoy & 102 & $37.8 \%$ \\
\hline
\end{tabular}

As can be observed from Table 2 above, English class fails to gain much popularity among the undergraduates surveyed. The percentages of the undergraduates who extremely enjoy, fairly enjoy, enjoy and not that enjoy English class are 8.1\%, 21.1\%, 33\% and 37.8\%, respectively. The largest proportion appears in those who not that enjoy English class, which shows a lack of satisfaction with the current English class among the undergraduates and poor effect of English teaching, thus making the English curriculum reform imperative. 


\subsection{Satisfaction with college English curriculum setting}

Prior to the questionnaire survey, the compositions of college English courses in Wuhan University of Science and Technology, Hubei University of Technology and Hubei University were obtained by referring to relevant information. The details are shown in Figure 1.

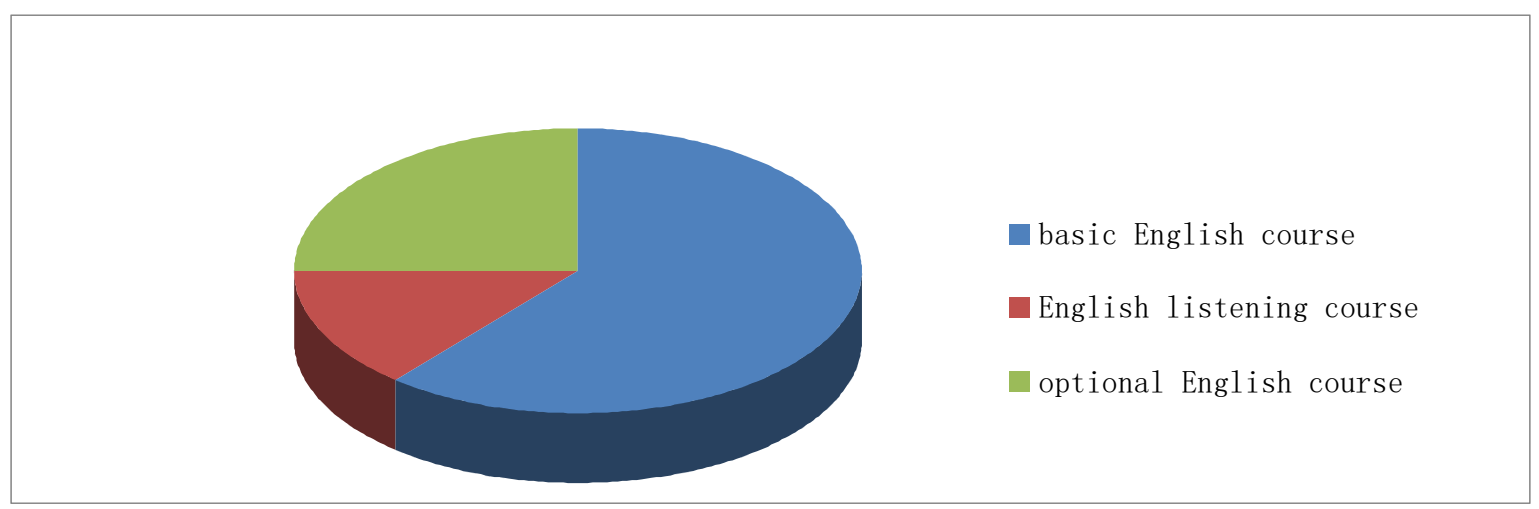

Figure 1 Composition of college English courses

Among the three universities, the basic English course on English grammar and sentence patterns accounts for 61\%, the largest proportion. The proportions of English listening course and optional English course are 14\% and 25\%, respectively. Despite the setting of optional English course in universities, the teachers still simply focus on basic skills.

Table 3 Satisfaction with college English curriculum setting

\begin{tabular}{|l|l|l|l|}
\hline Question & $\begin{array}{l}\text { Degree of } \\
\text { satisfaction }\end{array}$ & $\begin{array}{l}\text { Number of } \\
\text { persons }\end{array}$ & Percentage \\
\hline $\begin{array}{l}\text { Are you satisfied } \\
\text { with the college }\end{array}$ & $\begin{array}{l}\text { Extremely } \\
\text { Eatisfied }\end{array}$ & 9 & $3.3 \%$ \\
\cline { 2 - 4 } English course? & Fairly satisfied & 16 & $5.9 \%$ \\
\cline { 2 - 4 } & Satisfied & 28 & $10.4 \%$ \\
\cline { 2 - 4 } & Less satisfied & 91 & $33.7 \%$ \\
\cline { 2 - 4 } & Not satisfied & 126 & $46.7 \%$ \\
\hline
\end{tabular}

As Table 3 suggests, the proportions of the undergraduates who are extremely satisfied, fairly satisfied, satisfied, less satisfied and not satisfied with college English curriculum setting are respectively 3.3\%, 5.9\%, 10.4\%, 33.7\% and 46.7\%. The undergraduates show dissatisfaction with English course mainly because the grammars and vocabularies taught by the teachers fail to resonate with them, thereby resulting in a low degree of satisfaction with such courses among the undergraduates.

\section{Demand analysis of college English curriculum setting from the perspective of general education}

\subsection{Integrating the idea of general education is a new direction for college English curriculum setting}

In spite of some achievements in the past two decades, college English still show quite a few problems, especially in curriculum setting. The way of teaching rudimentary knowledge arouses dissatisfaction among the undergraduates, who find it difficult to acquire English knowledge, improve ability, understand the cultural differences between China and foreign countries, improve cultural literacy and English communication skills during the undergraduate study. They want 
longer English learning hours and diversified extracurricular English activities such as holding regular English lectures, encouraging students to start English clubs, and showing English movies. Meanwhile, the teachers are expected to shift from traditional "pouring" and "cramming" teaching modes to more interactions with students in the form of role play and games. Extended English courses are widely accepted by the undergraduates. They prefer cultural and knowledge courses, such as Advanced Intermediate and Advanced Spoken English, English Movie Appreciation, British and American Literature Appreciation, Intercultural Business Communication and Western Civilization and Culture. [5] From their point of view, these courses can improve their communication skills, spoken English and thinking ability while strengthening the understanding of foreign cultures, cultivating taste and broadening horizons. When analyzing the hierarchy of social demands, we discover that what employers emphasize are students' ability of applying the theories into practice, such as daily communication, intercultural business activities and writing English documents. [6]Such demands will be further highlighted in the increasingly broader scope of economic globalization. Therefore, in college English curriculum setting, universities should foster the students' listening and speaking skills, improve their sensitivity to and understanding of cultural differences, strengthen their ability of appreciating domestic and foreign cultures, thereby making students the real complete, sound and harmonious "man" and "citizen" mentioned in general education.

\subsection{The idea of general education affects students' English learning motivations}

One of the most important ideas of general education is to improve students' personality. It stresses students' personality shaping, objects to the inclination to professionalism, utilitarianism and specialization in modern education, and requires training the "whole man" with noble sentiments, a strong sense of social responsibility and correct value orientation. [7]College English as an important part of general education should make the best of teaching such that students are guided to understand foreign customs and cultures and absorb the essence of foreign cultures. [8]The goal of improving students' cultural literacy can thus be achieved. The teaching content of college English courses should also cover diversified, cross-cultural and interdisciplinary knowledge to widen students' scope of knowledge and improve teaching quality. Therefore, it is imperative to implement general education in universities.

\subsection{A new curriculum system setting for college English}

From the perspective of general education, college English should run throughout the undergraduate study, but it can be seen from the previous analysis that college English learning is still at the stage of fundamental learning and that it is necessary to set a new English curriculum system. [9] The new curriculum system consists of two aspects: implementation system and supporting system. The former includes curriculum objectives, class hours and curriculum content, while the latter comprises teaching method, faculty, English teaching materials and evaluation system. Class hours are arranged throughout the college study, namely required courses in the freshman and sophomore years, optional English courses in the junior year, and extended English courses in the senior year. [10]The curriculum content consists of five parts: 1)Courses at the elementary stage (including basic English listening, speaking, reading, writing and translation); (2) Courses at the improving stage which aims at enhancing students' comprehensive ability of using English (including advanced English reading, advanced English listening, writing and translation); (3) Courses at the extended stage (mainly cultural literacy and intercultural communication courses, including English movie appreciation, western civilization and culture, Chinese and western etiquette culture and customs, general introduction to English-speaking countries, British and American literature appreciation and business English); (4)Hidden courses; (5)Online courses. In college English, comprehensive English, cultural literacy, international English, listening, speaking, reading and writing courses should be integrated to ensure the cultivation of students' ability in all aspects. 


\section{Conclusions}

This study investigates the status quo of English curriculum setting in Hubei University, Wuhan University of Science and Technology and Hubei University of Technology. The findings reveal that: 1) The ideas of general education and teaching objectives of college English are inseparably interconnected; 2) Students have begun to realize the importance of college English. Simply imparting English knowledge will no longer satisfy the diversified requirements of students for English courses; 3) a new curriculum system setting for college English is proposed based on demand theory from the perspective of general education.

\section{Acknowledgements}

In this paper, the research was sponsored by Teaching and Researching Project of Hubei Province (Project No. 2016322).

\section{References}

[1] Boning K. (2007). Coherence in General Education: A Historical Look. The Journal of General Education, 56(1).

[2] Harvard University, Committee on the Objectives of a General Education in a Free Society. (1945). General Education in a Free Society: Report of the Harvard Committee. Cambridge: Harvard University Press.

[3]Needs analysis in language teaching[J] . Richard West. Language Teaching . 1994 (1)

[2]Making CALL work: Towards normalisation[J] . Andrea Chambers,Stephen Bax. System . 2006 (4)

[5]Second/Foreign Language Learning as a Social Accomplishment: Elaborations on a Reconceptualized SLA[J] . ALANFIRTH,JOHANNESWAGNER. The Modern Language Journal . 2007 (5)

[6]OUTPUT, INPUT ENHANCEMENT, AND THE NOTICING HYPOTHESIS. Shinichi Izumi. Studies in Second Language Acquisition . 2002

[7]Internet Technology-Based Projects in Learning and Teaching English as a Foreign Language at Yakutsk State University. Lena Zamorshchikova,Olga Egorova,Marina Popova. International Review of Research in Open and Distance Learning . 2011

[8]The language curriculum: A social contextual perspective. Kathleen Graves. Language Teaching . 2008

[9] Stephen, M.K., \& David, R.L. et al (2007). Report of the Task Force on General Education. Masschusattes: Harvard University Press.

[10] Stevens, A. H. (2001). The Philosophy of General Education and Its Contradictions: The Influence of Hutchins. Journal of General Education, 50(3), 165-191. 